\title{
STRATEGI PENGEMBANGAN AGRIBISNIS GULA AREN DI KABUPATEN SEKADAU
}

\author{
SURYANSYAH ${ }^{1)}$, NURLIZA ${ }^{2)}$, RADIAN $^{2)}$ \\ 1) Alumni Magister Manajemen Agribisnis Fakultas Pertanian Universitas \\ Tanjungpura Pontianak. \\ 2) Staf Pengajar Fakultas Pertanian Universitas Tanjungpura Pontianak
}

\begin{abstract}
Aren is a type of palm that has a highly potential economic value. Semabi, Sekadau Hilir Sub-district is the largest producer in the District of Sekadau; however, it is only processed to produce molded sugar. This study aimed to formulate a strategy for the palm sugar agrybusiness development in Sekadau District. The research method was a quantitative descriptive, and the data were processed using IFE/EFE, SPACE and SWOT. The values obtained from IFE and EFE matrixes were 2.57 and 2.65 respectively. From the SWOT analysis, alternative strategies were obtained, namely, SO Strategy: expanding the location of the area sugar palm cultivation, increasing production capacity, and improving the quality of product. WO Strategy: increasing of human resources (farmers), developing a partnership and developing a market information network. ST Strategy: government policies that supporting, increasing the added value and production. WT Strategy: building a support facility of sugar palm agribusiness, increasing coordination and cooperation among stakeholders in strengthening palm agribusiness, and increasing marketing and promotion for the expansion.
\end{abstract}

Keyword: Aren (palm), agrybusiness, IFE/EFE matrixes, SPACE matrix, and SWOT analysis.

\section{PENDAHULUAN}

Tanaman aren merupakan salah satu komoditas perkebunan yang memiliki nilai ekonomis yang tinggi sehingga sangat prospektif dalam pengembangannya dan memiliki peluang yang sangat besar dalam meningkatkan perekonomian suatu wilayah.

Nilai ekonomis yang dimiliki oleh produk-produk yang dihasilkan tanaman aren tersebut sangat dibutuhkan oleh pasar internasional sehingga mampu meningkatkan nilai ekspor yang berdampak pada peningkatan perekonomian nasional. Produk yang paling besar nilai ekonomisnya adalah gula aren. Tanaman aren (Arenga Pinnata) merupakan tanaman perkebunan yang sangat potensial dalam hal mengatasi kekurangan pangan dan mudah beradaptasi baik pada berbagai agroklimat, mulai dari dataran rendah sehingga $1400 \mathrm{~m}$ di atas permukaan laut (Effendi, 2009; Ditjen Perkebunan, 2004).

Secara teoritis potensi aren sebagai penghasil gula lebih tinggi dibandingkan tebu per satuan luas lahan, produksi gula yang dihasilkan tanaman aren 2,4 kali lebih besar dibandingkan tanaman tebu. Oleh karena itu, gula aren berpotensi menjadi komoditas substitusi gula pasir andalan di dalam negeri sehingga mampu menekan ketergantungan terhadap impor gula.

Sistem agribisnis gula aren memiliki peluang untuk dikembangkan akan tetapi peluang tersebut belum dimanfaatkan semaksimal mungkin. Pada 
umumnya, tanaman aren tumbuh begitu saja tanpa adanya budidaya dan animo masyarakat untuk mengembangkan tanaman aren tersebut masih sedikit yang disebabkan karena masyarakat takut akan resiko yang akan terjadi apabila mereka mengembangkan tanaman aren. Kepunahan tanaman aren yang memiliki banyak manfaatakan semakin cepat terjadi apabila tidak dikembangkan. Sehubungan dengan itu, pemerintah telah mulai menggalakkan tanaman aren dengan menganjurkan masyarakat membudidayakannya.

Kabupaten Sekadau merupakan salah satu sentra tanaman aren di Provinsi Kalimantan Barat, bahkan desa Semabi kecamatan Sekadau Hilir pada tahun 2008 pernah menjadi Pusat Kawasan Usaha Agribisnis Terpadu (KUAT) yang salah satu produk unggulannnya adalah gula aren. Hal ini disebabkan karena desa Semabi memiliki kondisi topografi yang mendukung dalam mengembangkan tanaman aren yaitu, berada pada ketinggian $520 \mathrm{~m}-1350 \mathrm{~m}$ dari permukaan laut dengan suhu rata-rata 25-30 derajat celcius dan memiliki curah hujan rata-rata $2142,92 \mathrm{~mm}$ per tahun dan $178,57 \mathrm{~mm}$ per bulan. Menurut Sunanto (1993), diIndonesia tanaman aren dapat tumbuh baik dan mampu berproduksi pada daerah-daerah yang tanahnya subur pada ketinggian500m 800m diatas permukaan laut dengan curah hujan yang merata sepanjang tahun, yaitu minimum sebanyak $1200 \mathrm{~mm}$ pertahun.

Pengembangan agribisnis gula aren di desa Semabi selain dapat meningkatkan pendapatan petani aren di kabupaten Sekadau, juga akan dapat menciptakan lapangan pekerjaanbaru bagi masyarakat yang berada disekitar kebun Aren sehingga mampu mengurangi tingkat pengangguran. Dengan demikian permasalahan yang akan diteliti dalam penelitian ini adalah bagaimanakah strategi pengembangan agribisnis gula aren di Kabupaten Sekadau, bagaimanakah analisis faktor lingkungan eksternal dan internal agribisnis gula aren di Kabupaten Sekadau, apa saja yang perlu dipertimbangkan dalam mengkaji strategi pengembangan agibisnis gula aren di Kabupaten Sekadau, serta alternatif dan prioritas strategi apa saja yang dapat diterapkan untuk mengembangkan agribisnis gula aren di Kabupaten Sekadau.

Kajian ini diharapkan bermanfaat sebagai referensi bagi pemerintah kabupaten Sekadau dalam penyusunan strategi dan alternatif kebijakan pengembangan agribisnis gula aren.Referensi bagi pelaku agribisnis gula aren dalam menentukan strategi pengembangan yang sesuai sehingga agribisnis gula aren menjadi lebih maju dan berkembang.Referensi bagi BAZNAS dalam mengembangkan program pendampingan dan pengembangan agribisnis gulaaren di kabupaten Sekadau melalui program pemberdayaan masyarakat BAZNAS (Zakat Community Development).Bagi penulis sendiri, penelitian ini merupakan sarana pengembangan wawasan dan pengembangan kemampuan analitis terhadap masalah-masalah praktis yang ada khususnya di bidang strategi pengembangan agribisnis gula aren.

Penelitian yang relevan berkaitan dengan penelitian ini adalahpenelitian Evalia (2014) strategi penguatan dan analisis nilai tambah aren di Kecamatan Lareh Sago Halaban. Tujuan dari penelitian ini adalah untuk mengetahui nilai tambah yang diperoleh dari agroindustri aren, mengidentifikasi lingkungan internal dan eksternal yang memengaruhi penguatan agroindustri aren serta strategi penguatan agroindustri aren di Kecamatan Lareh Sago Halaban.Penelitian ini dilakukan dengan metode deskriptif dan menggunakan analisisSWOT dan 
analisisnilai tambah.Penelitian ini lebih memfokuskan kepada strategi penguatan untuk kelompok tani pengusaha aren. Dari hasil penelitian ini didapatkan bahwa nilai tambah yang didapat dari pengolahan aren menjadi gula semut adalah sebesar $51,01 \%$.

Penelitian selanjutnya yang berkaitan dengan penelitian ini adalah penelitian oleh Rita Mariati (2013)Potensi Produksi dan Prospek Pengembangan Tanaman Aren di Kalimantan Timur.Hasil penelitian ini menyimpulkan bahwa prediksi perkembangan luas areal dan produksi tanaman aren di Kalimantan Timur menunjukkan peningkatan.Pengolahan dan pengelolaan produk tanaman aren yang dilakukan oleh petani/pengrajin aren di Kalimantan Timur masih terbatas pada pengolahan aren secara tradisional menjadi gula cetak sedangkan pengolahan nira aren menjadi gula semut dan bioethanol hanya terbatas pada uji coba. Berdasarkan analisis SWOT strategi pengembangan tanaman aren di Kalimantan Timur berada pada kuadran turn around dandevensif. Model pengembangan adalah pola kemitraan dengan membentuk kelompok usaha bersama.

Secara diagram keseluruhan kerangka pemikiran konseptual perumusan strategi pengembangan agribisnis gula aren di Kabupatenm Sekadau dapat dilihat pada gambar Berikut ini :

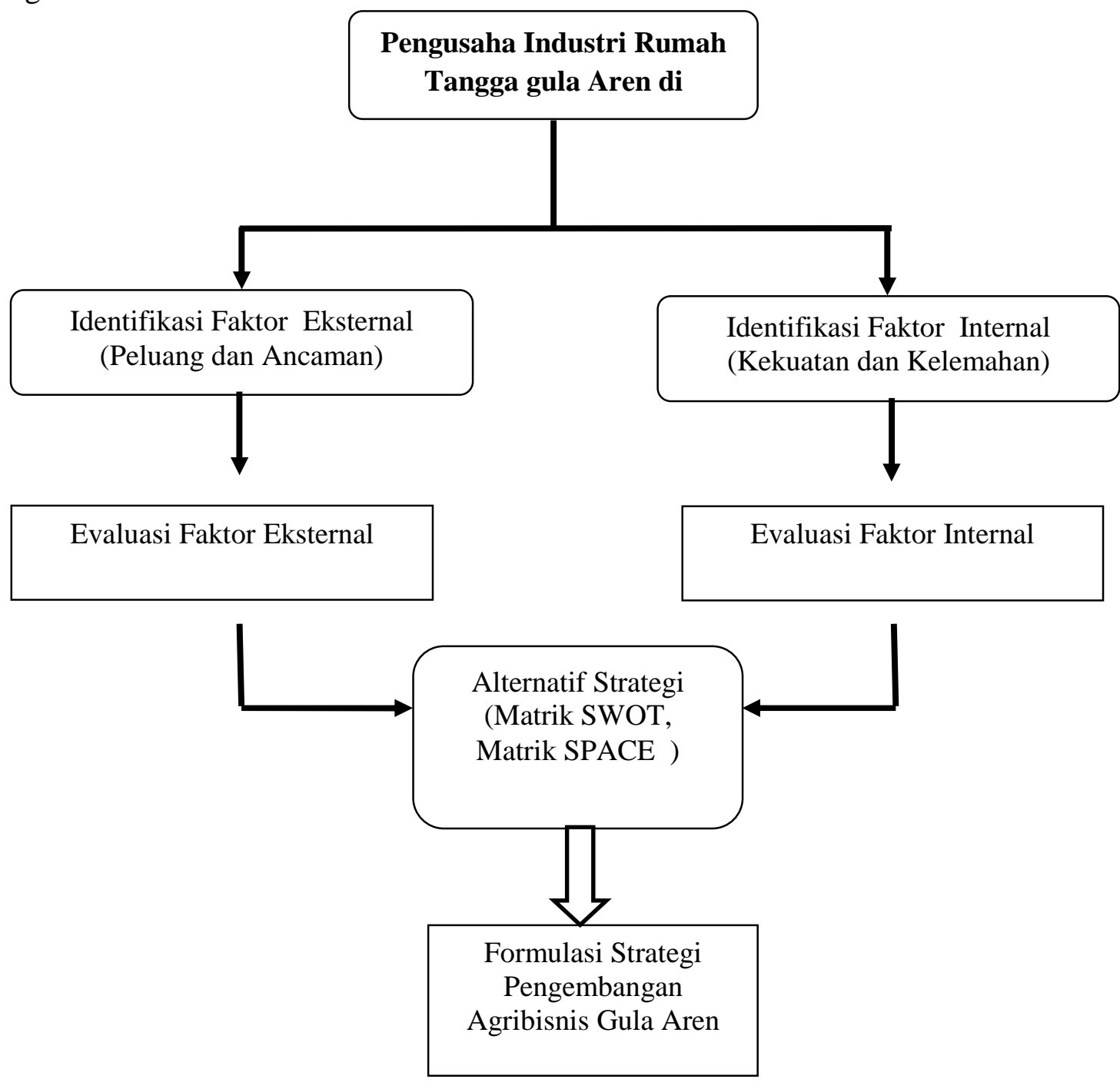




\section{METODE PENELITIAN}

Penelitian telah dilakukan di Kabupaten Sekadau Provinsi Kalimantan Barat, tepatnya di Desa Semabi Kecamatan Sekadau Hilir karena desa Semabi merupakan sentra penghasil gula aren yang terbesar di Kabupaten Sekadau. Jenis dan sumber data yang digunakan data primer dan data sekunder.Data primer, yaitu data yang diperoleh langsung dari narasumber dan responden.Penelitian strategi pengembangan agribisnis gulaaren ini menggunakan metode deskriptif. Pengumpulan data dalam penelitian ini menggunakan teknik studi literatur, pengamatan lapangan, wawancara dan diskusi dengan pakar dan pelaku agribisnis gula aren, serta pengisian kuesioner. Pengumpulan data juga dilakukan dengan melakukan wawancara dan memberikan kuesioner kepada responden, yaitu sebanyak 23 orang yang sudah dianggap mengerti dan paham dengan kondisi dan permasalahan mengenai agribisnis gula aren, yang terdiri dari kelompok pakar (Dinas Ketahanan Pangan, dan Perikanan, Dinas Koperasi UKM dan Perdagangan, BAZNAS dan KUAT Semabi) serta kelompok pelaku(petani, pedagang, supplier dan pesaing).

Analisis data dilakukan secara kualitatif dan kuantitatif. Data yang terkumpul dianalisis dengan menggunakan analisis deskriptif, IFE/EFE,dan analisis SWOT. Analisis deskriptif digunakan untuk mendeskriptifkan proses pengolahan gula aren yang dilakukan di desa Semabi Kecamatan Sekadau Hilir Kabupaten Sekadau, IFE/EFE digunakan untuk menganalisis fakor-faktor internal dan eksternal yang mempengaruhi strategi pengembangan agribisnis gula aren dan untuk melihat posisi agribisnis gula aren, SWOT untuk merumuskan alternatif strategi.

\section{HASIL DAN PEMBAHASAN}

Evaluasi faktor internal (IFE) dan eksternal (EFE)

Dalam mengevaluasi faktor-faktor internal yang mempengaruhi pengembangan agribisnis gula aren di Desa Semabi Kecamatan Sekadau Hilir Kabupaten Sekadau, telah dilakukan identifikasi terhadap faktor-faktor strategis internal yang meliputi aspek kekuatan dan kelemahan. Hasil wawancara dan kuesioner yang diberikan kepada responden didapatkan beberapa faktor secara internal yang terdiri dari lima faktor kekuatan dan limafaktor kelemahan. Faktor kekuatan terdiri atas: 1) luas lahan untuk pengembangan cukup besar, 2) ketersediaan bahan baku, 3) tersedianya petani dan petugas yang terampil, 4) kualitas produk gula aren yang baik, 5) memiliki keinginan untuk maju. Faktor Kelemahan terdiri atas: 1) kurangnya media promosi, 2) lemahnya pemasaran, 3) kemasan produk yang masih sederhana, 4) peralatan teknogi yang masih sederhana dan 5) belum adanya peremajaan tanaman aren.

Faktor lingkungan ekternal yang mempengaruhi pengembangan agribisnis gula aren dilihat dari aspek peluang dan ancaman, berjumlah 8 faktor yang terdiri dari empat faktor peluang dan empat faktor ancaman. Adapun faktor peluang terdiri atas: 1) tersedianya program pengembangan yang berkelanjutan, 2) terbukanya peluang pasar, 3) merupakan produk unggulan dan ciri khas daerah, 4) perkembangan sektor perhotelan dan pariwisata. Faktor ancaman terdiri dari: 1) belum adanya pengendalian harga dari pemerintah, 2) belum adanya regenerasi petani aren, 3) bertambahnya areal perkebunan sawit dan 4) banyaknya produk 
sejenis dari daerah lain. Hasil penilaian terhadap faktor-faktor internal dan eksternal dapa dilihat pada Tabel berikut.

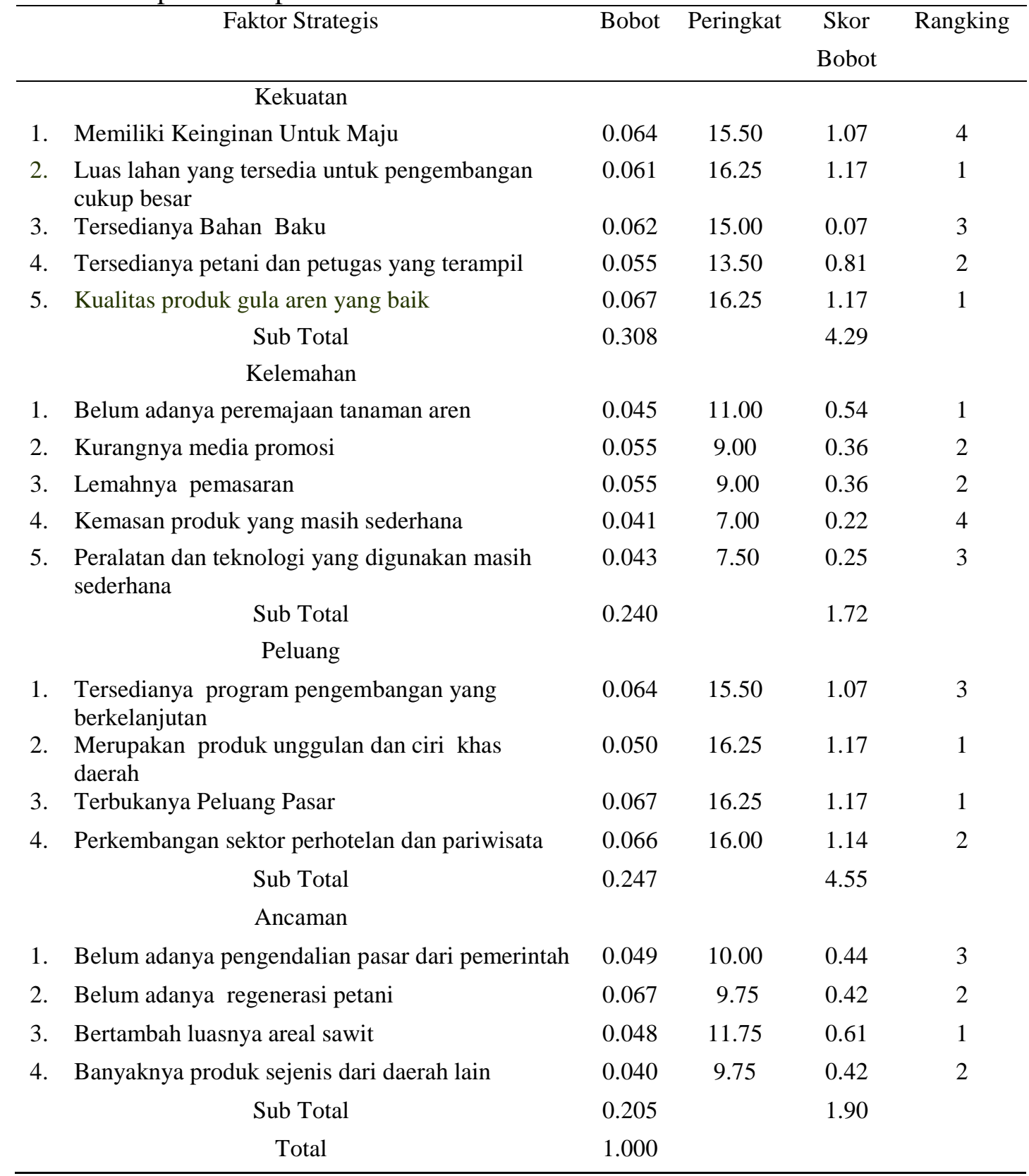

Total nilai yang diperoleh dari matriks IFE sebesar 2,57. Menurut David (2006), posisi nilai tersebut berada di atas nilai rata-rata tertimbang $(2,5)$. Kondisi tersebut menunjukkan secara internal posisi agribisnis gula aren saat ini adalah tinggi dalam memanfaatkan kekuatan-kekuatan dan berupaya untuk mengatasi kelemahan-kelemahan yang ada. Hal ini berarti pula bahwa secara internal, agribisnis gula aren memiliki kekuatan yang lebih dominan dari pada kelemahan dan memiliki potensi yang kuat untuk dikembangkan.

Faktor-faktor yang menjadi kekuatan utama yang dapat dimanfaatkan secara optimal dalam mengembangkan agribisnis gula aren adalah tersedianya luas lahan yang cukup besar untuk pengembangan tanaman aren dan kualitas produk gula aren yang baik (nilai 1,17 ), berikutnya adalah tersedianya petani dan 
petugas yang terampil (nilai 1,07), memiliki keinginan untuk maju (nilai 0,81 ) dan tersedianya bahan baku (nilai 0,07 ).

Faktor kelemahan yang dianggap memberikan pengaruh negatif kepada pengembangan agribisnis gula aren adalah belum adanya peremajaan tanaman aren (nilai 0,54), kurangnya media promosi dan lemahnya pemasaran (nilai0,36). Berikutnya adalah peralatan teknologi yang digunakan masih sederhana (nilai 0,25 ) dan kemasan produk yang masih sederhana (nilai 0,22) juga merupakan kelemahan yang harus dapat ditingkatkan agar produk gula aren mampu bersaing di pasar lokal,nasional maupun internasional.

Faktor yang menjadi peluang utama yang dapat dimanfaatkan dalam pengembangan agribisnis gula aren adalah tersedianya peluang pasar dan merupakan produk unggulan dan ciri khas daerah (nilai 1,17)merupakan peluang yang paling mungkin diraih oleh pengusaha agribisnis gula aren. Berikutnya perkembangan sektor perhotelan dan pariwisata (nilai 1,14) dan adanyaprogram pengembangan berkelanjutan (nilai 1,07) merupakan faktor peluang yang dapat dimanfaatkan dalam rangka pengembangan agribisnis gula aren.

Faktor yang menjadi ancaman terbesar dalam pengembangan agribisnis gula aren di kabupaten Sekadauadalah bertambah luasnya areal sawit (nilai 0,61). Hal ini perlu diwaspadai karena semakin bertambahnya areal sawit disatu sisi dan belum adanya peremajaan tanaman aren di sisi lain sangat mengancam keberlangsungan agribisis gula aren. Sedangkan faktor ancaman lainnya adalah belum adanya pengendalian pasar dari pemerintah (nilai 0,44 ), banyaknya produk sejenis dari daerah lain dan belum adanya regenerasi petani aren (nilai 0,42) juga merupakan ancaman yang harus diwaspadai dalam pengembangan agribisnis gula aren.

Nilai matrik IFE, kekuatan internal $(4,29)$ lebih besar dari kelemahan internal $(1,72)$. Nilai matrik $E F E$, peluang eksternal $(4,55)$ lebih besar dari ancaman eksternal $(1,90)$.

Hal ini menunjukkan bahwa dalam pengembangan agribisnis gula aren di Kabupaten Sekadau memiliki faktor kekuatan internal dan faktor peluang eksternal yang sangat besar sehingga dapat menggunakan seluruh faktor kekuatan yang dimiliki untuk menfaatkan peluang yang ada. Dari Matriks SPACE (Strategic Position And Action Evaluation) diketahui bahwa posisi strategis pengembangan agribisnis gula aren di Kabupaten Sekadau adalah dengan nilai internal sebesar 2,57 dan nilai eksternal sebesar 2,65.

Alternatif Strategi Pengembangan Agribisnis Gula Aren di Kabupaten Sekadau. Dengan menggunakan matriks SWOT didapatkan beberapa alternatif strategi pengembangan untuk dapat dilakukan yang terdiri dari strategi SO Strengths-Opportunuties, strategi WO (Weaknesses-Opportunuties ), strategi WT (Weaknesses - Threats) dan strategi ST (Strength-Threats) yang disajikan pada gambar berikut. 


\begin{tabular}{|c|c|c|}
\hline EFE & $\begin{array}{l}\text { Kekuatan (S) } \\
\text { 1. Tersedianya petani dan } \\
\text { petugas yang terampil } \\
\text { 2. Kualitas produk gula aren } \\
\text { yang baik } \\
\text { 3. Tersedianya Bahan Baku } \\
\text { 4. Memiliki keinginan untuk } \\
\text { maju } \\
\text { 5. Tersedianya lahan yang } \\
\text { luas untuk budidaya } \\
\text { tanaman aren }\end{array}$ & $\begin{array}{l}\text { Kelemahan (W) } \\
\text { 1. Belum adanya peremajaan } \\
\text { tanaman aren } \\
\text { 2. Kurangnya media promosi } \\
\text { 3. Lemahnya pemasaran } \\
\text { 4. Kemasan produk yang masih } \\
\text { sederhana } \\
\text { 5. Peralatan dan teknologi yang } \\
\text { digunakan masih sederhana }\end{array}$ \\
\hline 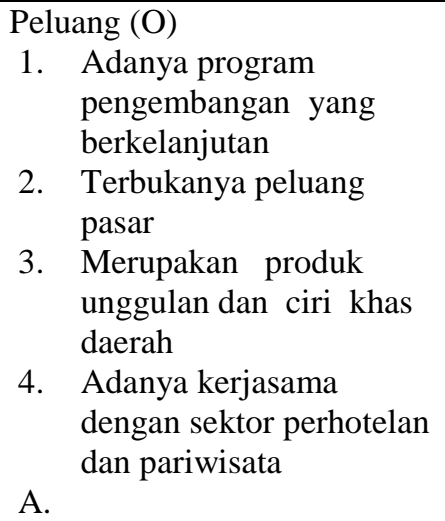 & $\begin{array}{ll}\text { Strategi S-O } \\
\text { 1. } \\
\begin{array}{l}\text { Mengembangkan lokasi } \\
\text { (areal) untuk budidaya }\end{array} \\
\text { tanaman aren (S5-O1) } \\
\text { 2. } \begin{array}{l}\text { Meningkatkan kapasitas } \\
\text { Produksi gula aren (S3,S4 }\end{array} \\
\text {-O2) } \\
\text { 3. Meningkatkan Kualitas } \\
\text { Pengolahan Gula Aren } \\
\text { (S3,S1 - O3) } \\
\text { 4. Memperluas daerah } \\
\text { pemasaran (S2-O4) }\end{array}$ & $\begin{array}{l}\text { Strategi W-O } \\
\text { 1. Meningkatkan SDM Petani } \\
\text { aren (W1-O1 dan O2) } \\
\text { 2. Mengembangkan pola } \\
\text { kemitraan (W4,W5 -O3,O4) } \\
\text { 3. Mengembangkan jaringan } \\
\text { informasi pasar(W2,W3 - } \\
\text { O2,O4) }\end{array}$ \\
\hline $\begin{array}{l}\text { Ancaman }(\mathrm{T}) \\
\text { 1. Luas areal sawitsemakin } \\
\text { bertambah } \\
\text { 2. Belum adanya regenerasi } \\
\text { petani } \\
\text { 3. Banyaknya produk } \\
\text { sejenis dari daerah lain }\end{array}$ & $\begin{array}{l}\text { Strategi S-T } \\
\text { 1. } \\
\text { Kebijakan pemerintah } \\
\text { yang mendukung } \\
\text { agribisnis gula aren } \\
\text { B. ( S3,S5 - T2,T3) } \\
\text { 2. Meningkatkan nilai } \\
\text { tambah dari produk yang } \\
\text { dihasilkan (S1,S2 - T1) }\end{array}$ & $\begin{aligned} & \text { Strategi W-T } \\
& \text { 1. } \text { Membangun fasilitas } \\
& \text { pendukung agribisnis gula } \\
& \text { aren. (W1 - T1) } \\
& \text { 2. } \text { Meningkatkan koordinasi } \\
& \text { dan kerjasama antar semua } \\
& \text { pihak terkait (W4,W5 - T2) } \text { Meningkatkan promosi } \\
& \text { 3. } \text { untuk memperluas } \\
& \text { pemasaran(W2,W3 - T3) }\end{aligned}$ \\
\hline
\end{tabular}

\section{Strategi SO menghasilkan empat alternatif strategi} yaitu:1)mengembangkan lokasi/areal untuk budidaya tanaman aren, yang dilakukan dengan menggunakan faktor kekuatan S5 (tersedianya lahan yang luas untuk budidaya tanaman aren) untuk memanfaatkan faktor peluang O1 (adanya program pengembangan berkelanjutan). Strategi ini dilakukan melalui kegiatan inventarisasi, pemetaaan, penentuan lahan-lahan yang dianggap potensial dan secara fungsional dapat dijadikan lahan pengembangan untuk budidaya/peremajaan tanaman aren serta tempat/sentra produksi gula aren;2)meningkatkan kapasitas produksi gula aren, yang dilakukan dengan menggunakan faktor kekuatan S3 (tersedianya bahan baku) dan S4 (memiliki keinginan untuk maju) untuk meraih peluang $\mathrm{O} 2$ (terbukanya peluang pasar).Strategi ini dapat dilakukan dengan cara melakukan inventarisasi, pemetaaan, penentuan lahan-lahan yang dianggap potensial dan secara fungsional dapat dijadikan lahan pengembangan untuk budidaya/peremajaan tanaman aren serta tempat/sentra produksi gula aren; 3) meningkatkan kualitas pengolahan gula aren, yang dilakukan dengan menggunakan faktor kekuatan S1 (tersedianya petani dan petugas yang terampil) dan faktor kekuatan S3 (tersedianya bahan baku) untuk memanfaatkan peluang $\mathrm{O} 3$ (merupakan produk unggulan dan ciri 
khas daerah).Tujuan dari strategi ini adalah untuk memenuhi kebutuhan dan kepuasan konsumen, memperkuat posisi produk dan agribisnis gula aren, serta memperluas pangsa pasar;4) memperluas daerah pemasaran, yang dilakukan dengan menggunakan faktor kekuatan S2 (kualitas produk gula aren yang baik) untuk memanfaatkan peluang O4 (adanya kerjasama dengan sektor perhotelan dan pariwisata).Penerapan strategi ini dapat dilakukan dengan cara menambah langganan pengumpul, ataupun dengan membuat sentra pemasaran gula aren yang siap menampung dan mamasarkan gula aren dari pengumpul, petani, maupun pedagang. Daerah pemasarannya dapat diperluas ke kota-kota besar di Kalimantan Barat seperti kota Pontianak dan kota Singkawang serta kota besar lainnya di Indonesia bahkan sampai ke manca negara baik dalam bentuk gula aren ataupun dalam bentuk gula semut dengan kemasan yang lebih menarik dan higienis.

Strategi WO menghasilkan tiga alternatif strategi yaitu: 1) meningkatkan SDM petani aren yang dilakukan dengan meminimalkan faktor kelemahan W1 (belum adanya peremajaan tanaman aren) untuk memanfaatkan peluang O1 (adanya program pengembangan yang berkelanjutan) dan O2 (terbukanya peluang pasar).Strategi ini bertujuan untuk meningkatkan pengetahuan dan keterampilan petani aren dalam pengelolaan usahanya, meningkatkan pembinaan, pendampingan dan pelatihan tentang manajemen usaha kepada petani dan kelompok tani disertai peningkatan peran penyuluh /pendamping ahli untuk membimbing dan membina petani agar termotivasi untuk merubah pola pikirnya, sehingga pengelolaan usaha gula arennya menjadi lebih baik;2) mengembangkan pola kemitraan untuk meminimalkan faktor kelemahan W4 (kemasanproduk yang masih sederhana) dan W5 (peralatan dan teknologi yang digunakan masih sederhana) untuk memanfaatkan peluang O3 (merupakan produk unggulan dan ciri khas daerah) dan $\mathrm{O} 4$ (adanya kerjasama dengan sektor perhotelan dan pariwisata).Dengan penerapan strategi ini diharapkan petani mempunyai akses kelembagaan keuangan untuk membantu permodalan, peningkatan keterampilan, kewirausahaan, adopsi teknologi, informasi, pemasaran, pembagian resiko dan keuntungan yang adil; 3)mengembangkan jaringan informasi pasar dilakukan untuk meminimalkan faktor kelemahan W2 (kurangnya media promosi) dan W3 (lemahnya pemasaran) untuk memanfaatkan faktor peluang O3 (merupakan produk unggulan dan ciri khas daerah) dan O4 (adanya kerjasama dengan sektor perhotelan dan pariwisata).Penerapan strategi ini dimaksudkan untuk memberikan pelayanan dan diseminasi informasi teknologi dan pemasaran.Pelayanan informasi dapat dilakukan terhadap hal- hal seperti peluang pasar, harga, standar kualitas, teknologi, sistem perdagangan, mitra usaha dan informasi lainnya yang diperlukan para pelaku agribisnis.

Strategi ST memiliki tiga alternatif strategi yaitu: 1) kebijakan pemerintah yang mendukung pengembangan agribisnis gula aren. Strategi ini dilakukan dengan menggunakan faktor kekuatan S3 (tersedianya bahan baku) dan S5 (tersedianya lahan yang luas untuk budidaya) untuk mengatasi ancaman T2 (luas areal sawit semakin bertambah) dan T4 (belum adanya regenerasi petani), 2) meningkatkan nilai tambah dari produk yang dihasilkan. Strategi ini dilakukan dengan menggunakan faktor kekuatan S1 (tersedianya petani dan petugas yang terampil) dan S2 (kualitas produk gula aren yang baik) untuk mengatasi ancaman T2 (luas areal sawit yang semakin bertambah).Nilai tambah (value 
added) adalah pertambahan nilai suatu komoditas karena mengalami proses pengolahan, pengangkutan, ataupun penyimpanan dalam suatu produksi. Pengolahan nira menjadi gula aren/gula semut merupakan pengolahan yang dilakukan untuk memperoleh nilai tambah.Perhitungan nilai tambah tersebut bertujuan untuk mengukur besarnyatambahan nilai yang dapat diperoleh petani dari pengolahan satu liter nira menjadi gula aren ataupun gula asemut.Strategi ini dapat dilakukan misalnya dengan meningkatkan kapasitas produksi gula semut yang harganya lebih mahal serta peluang pasarnya lebih luas hingga ke manca negara.

Strategi WT memiliki alternatif strategi yaitu: 1) membangun fasilitas pendukung agribisnis gula aren. Strategi ini dapat dilakukan dengan meminimalkan faktor kelemahan W1 (belum adanya peremajaan tanaman aren) dan menghindari ancaman T1 (luas areal sawit semakin bertambah).Strategi ini bertujuan untuk mendorong atau membantu kelancaran pelaksanaan pengembangan agribisnis gula aren di Kabupaten Sekadau. Penerapan strategi ini dapat dilakukan dengan cara meningkatkan program fasilitasi dan pembinaan terhadap petani aren seperti menambah rumah produksi, menambah peralatan produksi, membuat kemasan, merk dagang dan pelabelan, serta membuata pusat/sentra pemasaran gula aren; 2) meningkatkan koordinasi dan kerjasama antar semua pihak terkaityang dilakukan dengan meminimalkan faktor kelemahan W4 (kemasan produk yang masih sederhana) dan W5 (peralatan dan teknologi yang digunakan masih sederhana) dan menghindari ancaman T2 (belum adanya regenerasi petani aren), Strategi ini bertujuan untuk mewujudkan keterpaduan dalam pengembangan agribisnis gula aren di kabupaten Sekadau. Peningkatan kerjasama dan koordinasi yang baik antar instansi pemerintah terkait seperti Dinas Katahanan Pangan Pertanian dan Perikanan, Dinas Koperasi UKM dan Perdagangan, LSM, Sektor Perhotelan dan Pariwisata, Swasta, Pengusaha/Imvestor dan juga BAZNAS. Dengan demikian diharapkan dapat menggerakkan seluruh kelembagaan pelaku agribisnis, sehingga kegiatankegiatan perancanaan, pelaksanaan, pengawasan dan pembinaan dapat dilaksanakan dengan serasi dan berkesinambungan dan terpadu; 3)meningkatkan promosi untuk memperluas pemasaran, dilakukan dengan meminimalkan faktor kelemahan W2 (kurangnya media promosi), W3 (lemahnya pemasaran), dan menghindari ancaman T3 (Banyaknya produk sejenis dari daerah lain). Promosi adalah bagian yang penting dalam upaya perluasan pemasaran gula aren, ini mengingat bahwa produk gula aren belum terlalu familiar bagi semua orang sehingga perlu dilakukan promosi yang lebih gencar.Promosi juga dapat membangun image produk gula aren supaya lebih dikenal di pasaran.

Hasil analisis evaluasi faktor strategisinternal dan eksternal agribisnis gula aren menunjukkan bahwa faktor kekuatan (strength) mempunyai total skor 4,29 sedangkan kelemahan (weakness) total skor 1,72. Pada faktor eksternal menunjukan bahwa faktor peluang (opportunity) memilik total skor 4,55 sedangkan faktor ancaman (treats) memiliki total skor adalah 1,90. Rumusan kombinasi strategi matrik SWOT pengembagan agribisnis gula arendapat dilihat pada tabel berikut. 


\begin{tabular}{ccc}
\hline & Strength (S) & Weakness (W) \\
& & \\
\hline Opportunity (O) & Strategi SO: & Strategi WO: \\
& $4,29+4,55=8,84$ & $1,72+4,55=6,27$ \\
Threats (T) & Strategi ST: & Strategi WT: \\
& $4,29+1,90=6,19$ & $1,72+1,90=3,62$ \\
\hline
\end{tabular}

Sumber : Data Olahan, 2017

Berdasarkan tabel 2 di atas pengembangan agribisnis gula aren di Kabupaten Sekadau perlu memanfaatkan strategi S-O karena mempunyai nilai tertinggi yaitu 8,84 .

\section{KESIMPULAN DAN SARAN \\ Kesimpulan}

Kesimpulan yang dapat ditarik dalam penelitian ini adalah bahwa pengembangan agribisnis gula aren aren di Desa Semabi Kecamatan Sekadau Hilir Kabupaten Sekadau merupakan hal yang sangat penting untuk di implementasikan.Ini dilihat dari nilai faktor IFE senilai $(2,57)$ ini berarti secara internal sangat mendukung dalam pengembangan agribisnis gula aren kedepannya. Begitu juga dengan nilai EFE sebesar 2,65. Ini mengindikasikan bahwa masih banyak peluang-peluang yang belum dimanfaatkan dengan baik. Dari hasil penelitian juga didapatkan dua belas alternatif strategi yang mewakili dalam pengembangan agribisnis gula aren dari hulu ke hilir dalam upaya pengembangan agribisnis gulaaren, yang dapat diterapkan di Desa Semabi Kecamatan Sekadau Hilir Kabupaten Sekadau.

Prioritas strategi yang terpilih untuk dapat diimplementasikan adalah strategi S-O yang memiliki 4 program prioritas yaitu 1) mengembangan lokasi (areal) budidaya tanaman aren, melalui pemetaan dan inventarisasai lokasi pembibitan, peremajaan dan budidaya tanaman aren baik di lokasi yang sudah ada tanaman aren maupun di lokasi baru, 2) meningkatkan kapasitas produksi gula aren dengan cara membangun dan menambah jumlah rumah-rumah produksi tempat pembuatan gula aren pada satu kawasan terpadu/sentra produksi gula aren yang lebih modern, bersih dan higienis, melakukan pembinaan dan pelatihan tentang pengolahan dan kemasan gula aren, 3) meningkatkan kualitas produk gula aren dan menjaga mutu gula aren agar tetap higienis dilakukan dengan cara meningkatkan kualitas proses penyadapan air nira untuk mendapatkan bahan baku (air nira) yang baik, meningkatkan proses pengolahan gula aren yang higienis, dan penggunaan teknologi tepat guna yang sesuai. Tujuan dari strategi ini adalah untuk memenuhi kebutuhan dan kepuasan konsumen, memperkuat posisi produk dan perusahaan, dan memperluas pangsa pasar, 4) memperluas jaringan pemasaran melalui kerjasama kemitraan, membuat sentra pemasaran gula aren, dan memanfaatkan teknologi informasi.

\section{Saran}

Pengembangan agribisnis gula aren adalah hal penting yang harus dilakukan dan diharapkan pemerintah dapat lebih agresif untuk menindaklanjuti pengembangan tersebut. Hal ini disebabkan karena gula aren merupakan komoditas unggulan dan memberikan nilai tambah yang besar.Dalam rangka menjamin ketersediaan bahan 
baku tanaman aren diharapkan petani, pengusaha dan pemerintah dapat melakukan budidaya tanaman aren (pembibitan, penanaman/peremajaan, dan pemeliharaan) sehingga menjadi perkebunaan aren seperti halnya perkebunan sawit, meningkatkan kualitas produk dengan membuat kemasan yang lebih higienes dan menarik. Pengembangan SDM Petani dilakukan dengan memberikan pelatihan dan pendampingan tentang cara pembibitan/peremajaan tanaman aren, pengolahan dan pengemasan agar produk yang dihasilkan mampu bersaing baik dipasaran lokal, nasional maupun internasional. Pengembangan pola kemitraan yang dapat dikembangkan untuk meningkatkan nilai tambah ekonomi petani adalah pola hubungan kerjasama dengan sistem perusahaan pembimbing yaitu pola kerjasama petani dalam wadah kelompok atau KUD dengan perusahaan, pola pengembangan koperasi (KUD) dengan kelompok tani sebagai inti pengembangnya dan pola pengembangan Bapak Angkat, dimana yang bertindak sebagai Bapak Angkat adalah BUMN dan atau Swasta.

\section{DAFTAR PUSTAKA}

Agrifor Journal. Volume XII Nomor 2, Oktober 2013

David, Fred.R (2006). Manajemen Strategis: Konsep. Edisi kesepuluh. Penerbit PT Salemba Empat, Jakarta

Ditjen Perkebunan. (2004). Perkembangan aren di Indonesia.Prosiding Seminar Nasional Aren. Tondano, 9 Juni 2004. Balai Penelitian Tanaman Kelapa dan Palma Lain.hlm. 138-144.

Effendi. (2009). StudiKeterpaduan PasarDalamSistemPemasaran GulaArendi KabupatenLombokBarat NTB. Jurnal penelitian ilmu-ilmu sosial. PPSUB.Malang.

Hunger, David K. dan Thomas L. Wheelen. (2003). Manajemen Strategis. Penerbit Andi. Yogyakarta.

Jatmiko, Rahmad Dwi. (2003). Manajemen Stratejik. Edisi Pertama. Malang : UMM Press.

Kottler, P. (2001). Manajemen Pemasaran: Analisa, Perencanaan,Implementasi dan pengendalian. Edisi ke 7. Penerbit LPFE UI. Jakarta

Manaroinsong, E. Maliangkay, R.B. dan Mantana, Y.R. (2006). Observasi Produksi Nira Aren di Kecamatan Langowan, Kabupaten Minahasa Induk, Propinsi Sulawesi Utara.Buletin Palma No. 31.Pusat Penelitian dan Pengembangan Tanaman Perkebunan, Bogor.

Patmowiharjo.2000. Potensi Aren sebagai Tanaman Konservasi dan Ekonomi dalam Pengusahaan Hutan Rakyat.Warta Penelitian dan Pengembangan Tanaman Industri, Vol. 5, No. 4.

Peraturan Menteri Pertanian Republik Indonesia Nomo 133 Tahun 2013 tentang Pedoman Budidaya Aren

Rangkuti, Freddy . (2007). Teknik Membedah Kasus Bisnis. ( ANALISIS SWOT). Jakarta : Gramedia Pustaka.

Rangkuti, Freddy . (1997). Riset Pemasaran. Penerbit PT. Gramedia Pustaka Jakarta.

Rumokoi, M.M. (2004). Aren, Kelapa dan Lontar Sebagai Alternatif Pemenuhan Kebutuhan Gula Nasional.Prosiding Seminar Nasional Aren. Tondano..Balai Penelitian Tanaman Kelapa dan Palma Lain.9 Juni.

Sunanto,H. 1993. AREN: Budidaya dan Multigunanya.Penerbit.Kanisius. Jakarta

Undang Undang Republik Indonesia No. 18 Tahun 2004 tentang Perkebunan

Yasin, (2002) The Theory and Practice of Bencmarking: Then and Now Benchmarking. An International Journal 